\title{
PERENCANAAN PERSEDIAAN BAHAN BAKU ASAM PHOSPATE DENGAN KENDALA KETERBATASAN KAPASITAS GUDANG MENGGUNAKAN METODE FUZZY ECONOMIC ORDER QUANTITY DI PT. XYZ
}

\author{
Aditiya Pradana Putra ${ }^{(1)}$, Said Salim Dahda ${ }^{(2)}$, Dzakiyah Widyaningrum ${ }^{(3)}$ \\ Program Studi Teknik Industri, Universitas Muhammadiyah Gresik \\ Email : adputra000@gmail.com
}

\begin{abstract}
ABSTRAK
PT. XYZ mempunyai produksi utama yaitu asam fosfat. Pembuatan asam fosfat memerlukan 3 bahan baku utama yaitu asam sulfat,phospate rock, dan Anti foam. Pentingnya bahan baku dalam proses produksi membuat perusahaan memesan bahan baku dalam jumlah besar mengakibatkan menumpuknya stok bahan baku pada akhir bulan dan melebihi kapasitas dari gudang.

Fuzzy Economic Order Quantity with Limitation Storage yang merupakan metode penentuan ukuran pemesanan yang ekonomis dalam keadaan fuzzy menggunakan aturan aritmetika fuzzy untuk menghasilkan himpunan fungsi keanggotaan ukuran pemesanan dan biaya persediaan. Dengan menggunakan metode centroid untuk proses deffuzzifikasi dihasilkan ukuran pemesanan yang optimal dengan biaya persediaan yang minimal. Kuantitas pemesanan bahan baku dan ROP (Reorder Point )yang optimal untuk masing-masing bahan baku sebesar 3,808 MT dan ROP 8,309 MT atau 7 hari untuk asam sulfat, 26,311 MT dan ROP 26,865 MT atau 14 hari untuk Phospate rock dan 32,054 MT dengan ROP 24,519 MT atau 30 hari untuk Anti foam.

Besarnya biaya persediaan yang harus ditanggung oleh perusahaan sebesar Rp. 226,179,551 per bulan. Biaya total persediaan tersebut adalah hasil yang paling kecil jika dibandingkan dengan perhitungan menggunakan nilai tengah fuzzy permintaan sebesar Rp. 226,219,810 dan kondisi yang saat ini terjadi di mana rata-rata menghasilkan Rp. 398,521,926. Sehingga rata-rata penghematan per bulan yang dapat dihasilkan jika menggunakan fuzzy EOQ adalah Rp.172,076,517
\end{abstract}

Kata Kunci : Fuzzy Economic Order Quantity with Limitation Storage, deffuzzifikasi, metode centroid, Fuzzy 


\section{PENDAHULUAN}

PT. XYZ mempunyai 3 produk yang dihasilkan yaitu Asam Fosfat, Asam Sulfat dan Purified Gypsum. Asam Fosfat adalah produksi utama perusahaan yang digunakan sebagai bahan utama dalam pembuatan pupuk di PT. X.

Pentingnya bahan baku dalam proses produksi membuat perusahaan memesan bahan baku dalam jumlah besar sehingga mengakibatkan menumpuknya stok bahan baku pada akhir bulan, dan bahkan sampai beberapa bulan melebihi stok kapasitas gudang, sehingga terpaksa diletakkan di luar gudang dan dikhawatirkan dapat menurunkan kualitas bahan baku.

Selain dari kapasitas gudang, kebutuhan bahan baku yang naik turun (fluktuatif) mengakibatkan perusahaan kesulitan menemukan berapa jumlah pemesanan ekonomis sehingga beberapa kali terjadi kelebihan atau kekurangan stok. Adapun jenis pengendalian yang sudah dilakukan oleh PT. $\mathrm{XYZ}$ adalah metode min-max yaitu perusahaan melakukan pemesanan kembali saat baku menyentuh ROP (Reorder Point).

Untuk gudang penyimpanan bahan baku sendiri ada 2 yaitu tangki penyimpanan asam sulfat dengan kapasitas 60.000 matriks ton (MT) dan gudang bahan baku lainnya (Phospate Rock dan Anti foam) dengan kapasitas 80.000 matriks ton (MT). Adapun data penggunaan bahan baku, pembelian, dan kondisi penyimpanan bahan baku di PT. XYZ tahun 2018 dapat dilihat pada tabel 1.1,1.2, dan 1.3 .

Tabel 1.1 Data kebutuhan (pemakaian) bahan baku Asam Fosfat

PT. XYZ tahun 2018

\begin{tabular}{|l|l|l|l|}
\hline \multirow{2}{*}{ Month } & \multicolumn{3}{|c|}{$\begin{array}{c}\text { Raw Material Yang } \\
\text { Digunakan }\end{array}$} \\
\cline { 2 - 4 } & $\begin{array}{c}\text { Phospat } \\
\text { e Rock }\end{array}$ & $\begin{array}{c}\text { Sulphur } \\
\text { Acid } \\
\text { ing } \\
\text { Agent } \\
\text { (F- } \\
\text { Strike) }\end{array}$ \\
\cline { 2 - 4 } & MT & MT & MT \\
\hline January & 77,727 & 48,255 & 26,759 \\
\hline February & 64,038 & 29,150 & 22,797 \\
\hline March & 36,340 & 20,786 & 22,697 \\
\hline April & 49,147 & 40,217 & 21,957 \\
\hline May & 62,345 & 22,636 & 22,506 \\
\hline June & 51,054 & 25,495 & 34,329 \\
\hline July & 61,465 & 39,974 & 24,316 \\
\hline August & 56,834 & 46,356 & 13,985 \\
\hline $\begin{array}{l}\text { Septemb } \\
\text { er }\end{array}$ & 69,557 & 59,740 & 25,318 \\
\hline October & 42,872 & 38,100 & 58,433 \\
\hline $\begin{array}{l}\text { Novembe } \\
\text { r }\end{array}$ & 58,194 & 30,028 & 14,736 \\
\hline $\begin{array}{l}\text { Decembe } \\
\text { r }\end{array}$ & 61,231 & 26,581 & 14,397 \\
\hline Total & $\mathbf{6 9 0 , 8 0 4}$ & $\mathbf{4 2 7 , 3 1 8}$ & $\mathbf{3 0 2 , 2 3 7}$ \\
\hline & & Sumber : PT. XYZ) \\
\hline
\end{tabular}

Tabel 1.2 Pembelian bahan baku PT.XYZ tahun 2018

\begin{tabular}{|c|c|c|c|c|c|c|c|c|c|}
\hline \multirow{3}{*}{ Bulan } & \multicolumn{9}{|c|}{ Bahan Baku } \\
\hline & \multirow{2}{*}{\begin{tabular}{|c}
$\begin{array}{c}\text { Phospat } \\
\text { e Rock }\end{array}$ \\
MT \\
\end{tabular}} & \multirow{2}{*}{$\begin{array}{l}\text { Fr } \\
\text { ek } \\
\text {. }\end{array}$} & \multirow[t]{2}{*}{ Jumlah } & \multirow{2}{*}{\begin{tabular}{|c}
$\begin{array}{c}\text { Sulph } \\
\text { ur } \\
\text { Acid }\end{array}$ \\
MT \\
\end{tabular}} & \multirow[t]{2}{*}{$\begin{array}{l}\text { Fr } \\
\text { ek }\end{array}$} & \multirow[t]{2}{*}{ Jumlah } & \multirow{2}{*}{$\begin{array}{c}\begin{array}{c}\text { Defoamin } \\
\text { g-Agent } \\
\text { (F-Strike) }\end{array} \\
\text { MI }\end{array}$} & \multirow[t]{2}{*}{$\begin{array}{l}\mathrm{Fr} \\
\mathrm{ek}\end{array}$} & \multirow[t]{2}{*}{$\begin{array}{c}\text { Jamla } \\
\text { h }\end{array}$} \\
\hline & & & & & & & & & \\
\hline Jamuary & 4,630 & 10 & 46,300 & $\begin{array}{c}16,62 \\
1\end{array}$ & 3 & 49,863 & 22,108 & 1 & 22,108 \\
\hline February & 4,423 & 10 & 44,280 & $\begin{array}{c}11,96 \\
1\end{array}$ & 4 & 47,843 & 10,534 & 1 & 10,534 \\
\hline March & 5,050 & 9 & 45,450 & $\begin{array}{c}11,90 \\
7\end{array}$ & 2 & 23,814 & & & \\
\hline April & 6,509 & 10 & 65,090 & $\begin{array}{c}11,00 \\
9\end{array}$ & 4 & 44,035 & & & \\
\hline May & 12,838 & 1 & 12,833 & $\begin{array}{c}10,37 \\
8\end{array}$ & 2 & 20,755 & & & \\
\hline June & 8,424 & 7 & 38,968 & $\begin{array}{c}15,66 \\
3 \\
\end{array}$ & 3 & 46,988 & 18,024 & 1 & 18,024 \\
\hline July & 5,107 & 15 & 76,605 & $\begin{array}{c}15,58 \\
5\end{array}$ & 3 & 46,754 & 19,040 & 1 & 19,040 \\
\hline August & 6,768 & 8 & 54,144 & $\begin{array}{c}25,62 \\
4\end{array}$ & 2 & 51,248 & & & \\
\hline $\begin{array}{c}\text { Septemb } \\
\text { er }\end{array}$ & 6.550 & 12 & 78,600 & $\begin{array}{c}10,07 \\
3\end{array}$ & 6 & 60,439 & 11,004 & 1 & 11,004 \\
\hline Detober & 8,043 & 11 & 88,523 & $\begin{array}{c}12,81 \\
2\end{array}$ & 3 & 38,436 & 31,088 & 1 & 31,088 \\
\hline $\begin{array}{c}\text { Noremb } \\
\text { er }\end{array}$ & 6.214 & 7 & 43,498 & $\begin{array}{c}22,97 \\
8 \\
\end{array}$ & 2 & 45,955 & & & \\
\hline $\begin{array}{c}\text { Decembe } \\
\text { I }\end{array}$ & & & & $\begin{array}{c}25,00 \\
1 \\
\end{array}$ & 2 & 50,001 & & & \\
\hline Total & & $\begin{array}{c}10 \\
0 \\
\end{array}$ & 614,301 & & 36 & 526,131 & & 6 & $\begin{array}{c}111,80 \\
0\end{array}$ \\
\hline
\end{tabular}


Tabel 1.3 Kondisi kapasitas gudang bahan baku tahun 2018

\begin{tabular}{|c|c|c|c|c|c|}
\hline \multirow[t]{2}{*}{ Bulan } & \multicolumn{2}{|c|}{$\begin{array}{c}\text { Persediaan Awal } \\
\text { Bulan + Pembelian } \\
\text { (MI) }\end{array}$} & \multirow[t]{2}{*}{ Total } & \multirow[t]{2}{*}{ Kapasitas } & \multirow[t]{2}{*}{ Status } \\
\hline & $\begin{array}{c}\text { Phospate } \\
\text { Rock }\end{array}$ & $\begin{array}{l}\text { Anti } \\
\text { Foam }\end{array}$ & & & \\
\hline Jamuary & 119,372 & $27,048.62$ & 146,421 & 80,000 & Kurang \\
\hline Fetnary & 100,733 & $25,684.88$ & 126,418 & 80,000 & Kurang \\
\hline March & 78,259 & $23,435.23$ & 101,694 & 80,000 & Kurang \\
\hline April & 114,844 & $21,985.99$ & 136,830 & 80,000 & Kurang \\
\hline May & 96,177 & $23,040.21$ & 119,217 & 80,000 & Kurang \\
\hline June & 92,604 & $36,822.60$ & 129,427 & 80,000 & Kurang \\
\hline July & 97,386 & $26,096.80$ & 123,483 & 80,000 & Kurang \\
\hline August & 85,016 & $14,013.25$ & 99,029 & 80,000 & Kurang \\
\hline September & 104,749 & $27,634.07$ & 132,383 & 80,000 & Kurang \\
\hline October & 128,255 & $58,723.72$ & 186,979 & 80,000 & Kurang \\
\hline Noriember & 129,807 & $14,797.87$ & 142,605 & 80,000 & Kurang \\
\hline December & 71,612 & $14,449.54$ & 83,062 & 80,000 & Kurang \\
\hline Total & $1,218,814$ & 313,733 & & & \\
\hline
\end{tabular}

(Sumber : PT. XYZ)

Pada tabel 1.3. dapat dilihat bahwa data kebutuhan bahan baku yang digunakan mengalami fluktuasi karena ketidakpastian jumlah pembelian bahan baku. Dikarenakan ketidakpastian yang terjadi pada pemesanan bahan baku, maka diperlukan model penentuan jumlah pemesanan yang optimal. Menurut Syed dan Azis dalam (Efendi, 2015) bahwa ketidakpastian permintaan yang terjadi seperti di (tabel 1.3) di mana fluktuasi permintaan akan sulit dioptimalkan untuk didekati dengan teori probabilitas akan lebih mudah didekati dengan teori himpunan fuzzy, sehingga biaya persediaan yang timbul dapat ditekan dan tidak terdapat kekurangan persediaan.

Fuzzy sendiri menurut Zadeh dalam (Sulistiawan \& Pribadi, 2017) merupakan suatu kerangka pemikiran untuk menganggap parameter-parameter yang tidak atau kurang jelas didefinisikan atau nilainya tidak tepat atau ditentukan secara subyektif. Model fuzzy sendiri merupakan model nilai yang diharapkan untuk menemukan kuantitas pesanan ekonomi yang optimal, yang akan meminimalkan nilai fuzzy yang diharapkan dari total biaya, sehingga kredibilitas total biaya tidak melebihi tingkat anggaran tertentu (Samal \& Pratihar, 2014). Angka fuzzy yang paling umum digunakan adalah angka fuzzy segitiga dan trapesium (Liu, 2008). Maka digunakan teori himpunan fuzzy representasi kurva triangular atau bisa disebut triangular fuzzy number. Menurut (Dahdah, 2009), jika perusahaan tidak mempunyai data yang cukup untuk menentukan variabel permintaan, untuk mengatasi ketidakpastian variabel yang mempunyai pola tersebut digunakan angka fuzzy untuk membantu mengatasi permasalahan tersebut sehingga memunculkan model fuzzy untuk penentuan ukuran pemesanan yang ekonomis atau yang dikenal dengan Fuzzy Economic Order Quantity.

\section{TINJAUAN PUSTAKA}

\section{Model Statis EOQ}

Tujuan model ini adalah untuk menentukan jumlah $(\mathrm{Q})$ setiap kali pemesanaan (EOQ) sehingga meminimasi biaya total persediaan dimana:

$$
Q=\sqrt{\frac{2 C r D}{c h}}
$$

Keterangan:

$\mathrm{D} \quad=$ jumlah permintaan per periode (unit) 
$\mathrm{Ch}=$ biaya simpan per periode (Rp/unit/periode)

$\mathrm{Cr}=$ biaya pemesanan per periode (Rp/pesan)

$\mathrm{Q} \quad=$ kuantitas pemesanan yang optimal (unit)

$\mathrm{P}=$ harga satuan unit (Rp/unit)

$\mathrm{I}=$ biaya simpan dalam persentase persediaan $(\%)$

\section{Model Statis EOQ Banyak Item dengan}

\section{Keterbatasan Gudang}

Model ini membahas sistem persediaan yang melibatkan banyak jenis barang $(n>1)$ dimana barang-barang tersebut akan disimpan pada sebuah gudang yang luas ruangannya terbatas.

Langkah pertama kita adalah memeriksa apakah fungsi pembatas aktif dengan cara menguji apakah nilai bukan pembatas, yaitu:

$$
Q_{i} \text { optimal }=\sqrt{\frac{2 D_{i} k_{i}}{h_{i}}}
$$

Memenuhi pembatas luas gudang (A). Jika "ya", maka fungsi pembatas tersebut diabaikan. Jika "tidak", maka fungsi pembatas haru berlaku (aktif) dimana nilai optimal yang baru dari Q (Qi) harus dicari sehingga memenuhi pembatas gudang, demikian juga kebalikannya

\section{FUZZY}

Ada beberapa definisi Fuzzy untuk membentuk Fuzzy EOQ (Dahdah, 2009).

\section{Definisi 1.}

Sebuah himpunan fuzzy $r$ didefinisikan sebagai fungsi keanggotaan dari $\mu r(r)$ yang mana memetakan masing-masing dan setiap elemen dari $R$ ke rentang antara 0 sampai 1 , atau dapat dituliskan dengan $\mu r(r) \rightarrow[0,1]$ Dimana $R$ adalah himpunan universal. Diartikan secara sederhana, Himpunan fuzzy adalah himpunan yang tidak mempunyai batasan secara tegas. Disisi yang lain, Sebuah himpunan fuzzy adalah himpunan yang memiliki elemen dengan karakteristik seperti pada fungsi keanggaotaan diatas.

\section{Definisi 2.}

Bilangan Fuzzy $r$ adalah sebuah himpunan fuzzy yang didefinisikan dalam $R$ yang mempunyai tingkat keanggotaan $\mu \dot{r}(r)$, dimana $r \in R$ dengan asumsi:
a. Convex
b. Normalized fuzzy set
c. Piecewise Continuous

Definisi 3.

Misalkan $r$ adalah bilangan fuzzy, $a$-cut dari $r$ dinotasikan dengan $r a$ adalah himpunan bilangan nyata yang mana fungsi keanggotaan $r$ tidak lebih kecil dari $a$. Dapat dituliskan dalam bentuk

$$
\tilde{r} a=\{r \mathrm{I} \mu \tilde{r}(r) \geq a, r \in R\}
$$

\section{Definisi 4.}

Support dari satu himpunan fuzzy adalah sebuah himpunan bagian bilangan crisp (tegas) dari himpunan dasar $R$. Dapat dituliskan dalam bentuk

$$
\operatorname{Supp}(\tilde{r})=\{r \mathrm{I} \mu \tilde{r}(r) \geq 0, r \in R\}
$$




\section{Definisi 5.}

Fungsi keanggotaan adalah suatu kurva yang menunjukkan pemetaan nilai data input (domain) ke nilai keanggotaannya dengan cara mendakati dengan suatu bentuk fungsi. Salah satu fungsi keanggotaan (kurva) adalah triangular/segitiga (tria gular fuzzy number). Bentuk kurva ini seperti pada gambar, dimana $r$ ditujukan dengan $(\mathrm{a}, \mathrm{b}, \mathrm{c})$, dimana $\mathrm{a} \leq \mathrm{b} \leq \mathrm{c}$ dan fungsi keanggotaan didefinisikan sebagi berikut:

$\mu_{\tilde{r}}(r)=\left\{\begin{array}{cc}0 & x \leq a ; x \geq c \\ \frac{x-a}{b-a} & a \leq x \leq b \\ \frac{b-x}{c-b} & b \leq x \leq c\end{array}\right.$

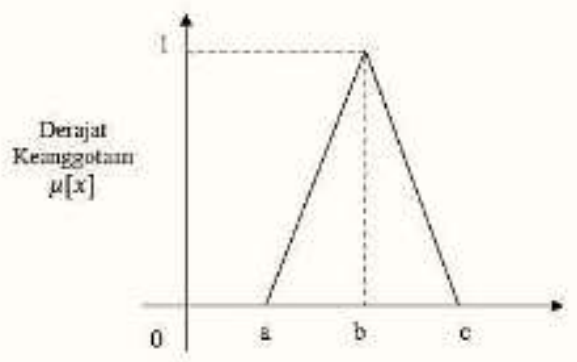

Dimana, a, b, c $\in R$

Keterangan:

$\mathrm{a}=$ nilai domain terkecil yang mempunyai derajat keanggotaan nol

$\mathrm{b}=$ nilai domain yang mempunyai derajat keanggotaan satu

$\mathrm{c}=$ nilai domain terbesar yang mempunyai derajat keanggotaan nol

$r=$ nilai input yang akan di ubah ke dalam bilangan fuzzy

Definisi 6.
Dengan menggunakan konsep definisi 3, apabila diberikan koefisien confidence bilangan fuzzy segitiga akan didefinisikan sebagai himpunan dengan interval tertutup. Interval tersebut adalah

$$
\tilde{r} a=\left(\tilde{r}_{a-L} ; \tilde{r}_{a-U}\right)=\{a+a(b-a) ; c-a(c-b)\} \forall a \in[0,1]
$$

Definisi 7.

Proses penegasan (de-fuzzifikasi) keluaran dari suatu aturan-aturan fuzzy merupakan domain himpunan fuzzy yang harus dapat dirubah menjadi bilangan tegas (crisp). Ada beberapa metode yang digunakan untuk proses defuzzifikasi salah satu yang didigunakan pada metode ini adalah metode pusat gravitasi (centre of gravity) atau centroid yang meruapakan metode yang paling terkenal dan efisien (Sinha dan Sarmah). $r$ diubah menjadi bilangan tegas dengan rumusan

$$
r=\text { Defuzzikasi, } \tilde{r}=\frac{\int_{R} r \cdot \mu_{r}(r) d r}{\int_{R} \mu_{\tilde{r}}(r) d r}
$$

Dalam kaitan dengan penggunaan fuzzy pada penentuan ukuran pemesanan yang ekonomis, dengan variabel permintaan yang bersifat deterministik akan diubah menjadi fuzzy permintaan maka akan mengakibatkan berubahnya bentuk ukuran pemesanan yang ekonomis menjadi fuzzy ukuran pemesanan yang ekonomis $Q^{*}$. Rumusan akan berubah menjadi (Dahdah, 2009).

$$
\tilde{Q}^{*}=\sqrt{\frac{2 . c . D}{h}}
$$

Dimana $D$ adalah bilangan fuzzy permintaan dengan fungsi keanggotaanmerepresentasikan 
Vol. 1, No. 4, 2020

kurva segitiga (triangular). Sebuah bilangan

fuzzy $\tilde{D}$ didefinikan dengan support $\left[D_{i} ; D_{U}\right]$

dengan titik $D_{m}$ merupakan maksimal derajat

keanggotaan. Dimana $\tilde{D}=\left[D_{i} ; D_{m} ; D_{U}\right]$ dan $D_{i} ; D_{m} ; D_{U} \in R$, dimana $D_{i}$ adalah batas bawah permintaan, Dm adalah nilai tengah permintaan dan $D_{U}$ adalah batas pemintaan.

Derajat keanggotaan $D_{i}$ dan $D_{U}$ adalah 0 dan derajat keanggotaan Dm mencapai angka 1. Begitu halnya dengan biaya persediaan yang akan berubah menjadi

$$
T \tilde{I} C=h \cdot \frac{Q}{2}+c \cdot \frac{\tilde{D}}{Q}
$$

Jika ukuran pemesanan yang optimal tidak diikutkan dalam perhitungan maka didapat rumus;

$$
\tilde{T I C}=\sqrt{\text { 2.h.c. } \tilde{D}}
$$

Metodologi ini digambarkan tahap-tahap yang akan dilakukan dalam penelitian. Metode ini dimulai dari identifikasi masalah sampai dengan pengambilan kesimpulan akhir melalui diagram alir yang ditampilkan dibawah ini.

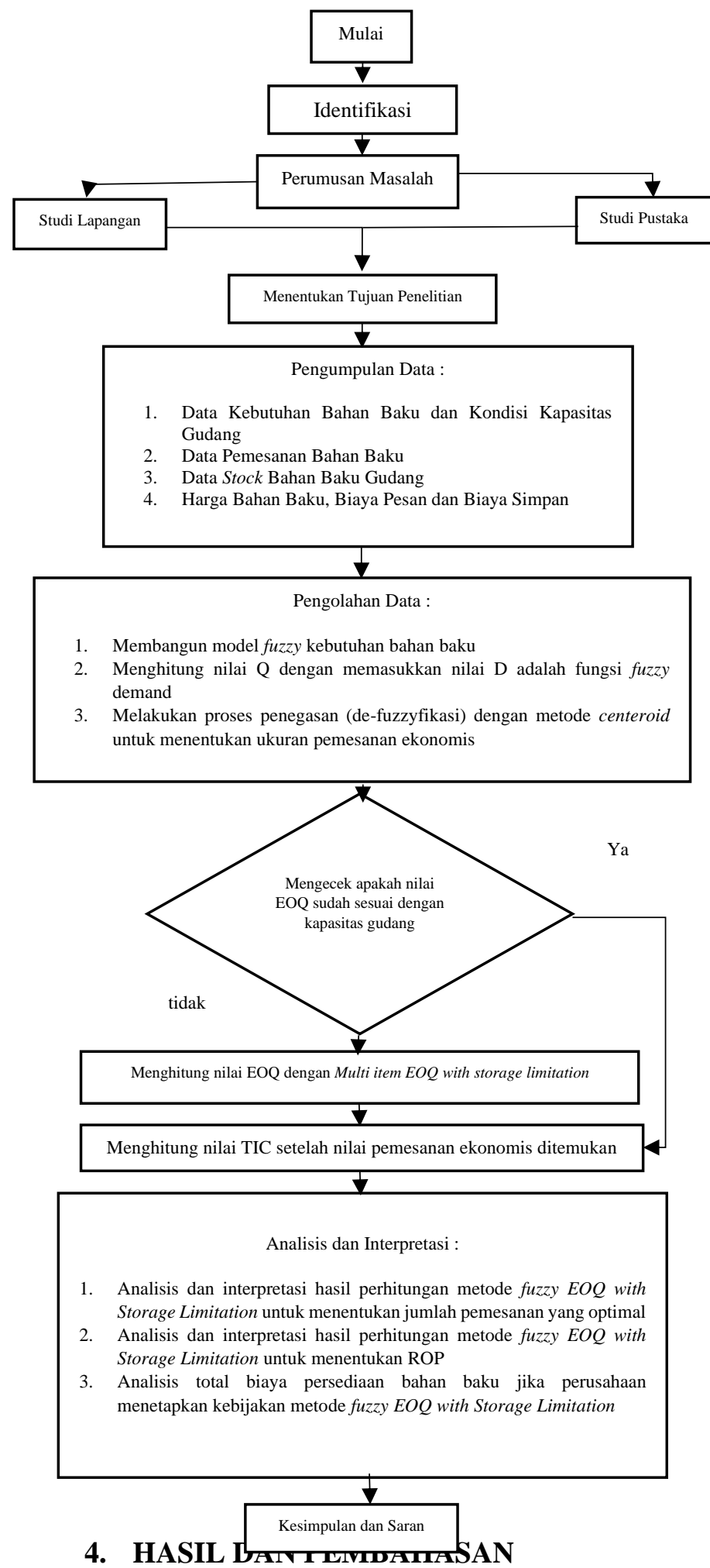




\section{Penentuan pemesanan yang optimal}

Diketahui bahwa rincian biaya pesan dan biaya simpan pada ke tiga bahan baku adalah:

Tabel 4.1 Biaya pesan dan simpan bahan baku

\begin{tabular}{|c|c|c|}
\hline & Biaya Pesan & $\begin{array}{c}\text { Biaya } \\
\text { Simpan }\end{array}$ \\
\hline Asam Sulfat & Rp. 1.170.916 & \multirow{2}{*}{$1,08 \%$} \\
\cline { 1 - 2 } Phospate rock & Rp. 462.586 & \multirow{2}{*}{$1,089.990$} \\
\hline Anti foam & Rp. 7.089. \\
\hline
\end{tabular}

Derajat keanggotaan $\mu_{r}(r)$

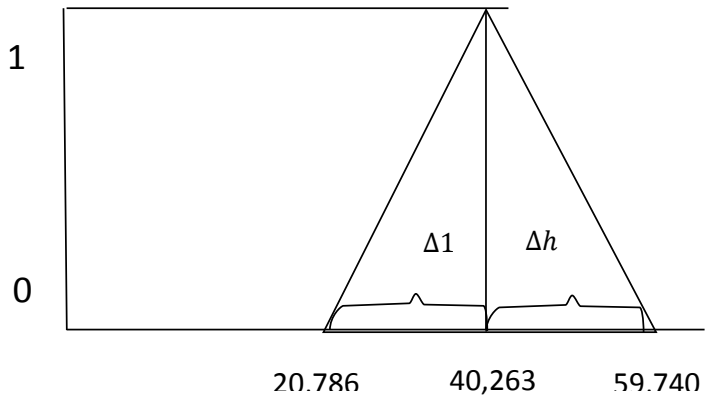

Dengan fungsi keanggotaan

$$
\mu_{r}(r)=\left\{\begin{array}{cl}
\frac{x-a}{b-a} & x \leq 20,786 ; x \geq 59,740 \\
\frac{b-x}{c-b} & 40,786 \leq x \leq 40,263 \leq x \leq 59,740
\end{array}\right.
$$

Setelah fungsi keanggotaan dimasukkan dengan data kebutuhan bahan baku asam sulfat, selanjutnya digunakan untuk menentukan ukuran permintaan dalam fuzzy demand (D) dengan rumus :

$$
\tilde{D}=\{a+a(b-a) ; c-a(c-b)\} \forall a \in[0,1]
$$

Sehingga ( $\tilde{D})$ asam sulfat adalah:

$$
\begin{aligned}
& \widetilde{D}=\{20,786+\alpha(40,263-20,786) \\
& \quad 59,740-\alpha(59,740-40,263)\} \forall \alpha \in[0,1]
\end{aligned}
$$

$$
\begin{gathered}
\tilde{D}=\{20,786+19,477 a ; 59,740-19,477 a\} \\
\forall a \in[0,1]
\end{gathered}
$$

Setelah itu menentukan nilai $\alpha$ dengan rumus :

$$
\begin{array}{ll}
\tilde{y}_{i}^{*} & =\frac{\left.\sqrt{2 \cdot K_{i \cdot}(a+a(b-a)}\right)}{h_{i}}, i=1,2, \ldots \ldots, n \\
\tilde{y}_{i}{ }_{i}=\frac{2 \cdot K_{i \cdot}(a+a(b-a))}{h_{i}} & , i=1,2, \ldots \ldots, n
\end{array}
$$

Dan,

$$
\begin{gathered}
\tilde{y}_{i}^{*}=\frac{\left.\sqrt{2 \cdot K_{i} \cdot(c-a(c-b)}\right)}{h_{i}}, i=1,2, \ldots \ldots, n \\
\tilde{y}_{i}{ }_{i}=\frac{2 \cdot K_{i} \cdot(c-a(c-b))}{h_{i}}, i=1,2, \ldots \ldots, n
\end{gathered}
$$

Kemudian menentukan ukuran pemesanan yang ekonomis dengan rumus:

$$
\tilde{y}_{i}^{*}=\frac{\sqrt{2 \cdot K_{i} \cdot \tilde{D}_{i}}}{h_{i}}
$$

Sehingga memunculkan fungsi keanggotaan untuk pemesanan yang ekonomis dalam bentuk fuzzy $\left(\tilde{y}_{i}\right)$ adalah:

$\mu_{r}(r)$

$=\left\{\begin{array}{cl}0 & x \leq 2,857.62 ; x \geq 4,844.52 \\ \left(1,3069 \times 10^{-7}\right) y^{2}-1,0672 & 2,857.62 \leq y \leq 3977.14 \\ 3067-\left(1,3069 \times 10^{-7}\right) y^{2} & 3977.14 \leq y \leq 4,844.52\end{array}\right.$

Selanjutnya dilakukan penegasan (defuzzyfikasi) dengan metode centeroid sehingga didapatkan ukuran pemesanan ekonomis bahan baku asam sulfat sebesar 3,808 MT.

$$
\begin{gathered}
\sum_{i=1}^{n} m_{i} y_{i} \leq A \\
3,808 \leq 60.000
\end{gathered}
$$


Dikarenakan nilai $\quad \sum_{i=1}^{n} m_{i} y_{i} \leq A \quad$ sudah memenuhi kendala kapasitas gudang maka perhitungan tidak dilanjutkan.

Tabel 4.2 Ukuran pemesanan optimal bahan baku pembantu

\begin{tabular}{|c|c|c|c|c|}
\hline \multirow{2}{*}{$\begin{array}{c}\text { Bahan } \\
\text { baku }\end{array}$} & \multicolumn{3}{|c|}{ Fungsi Keanggotaan } & \multirow{2}{*}{$\widetilde{\boldsymbol{y}}($ MT) } \\
\cline { 2 - 4 } & a & b & c & \\
\hline $\begin{array}{c}\text { Phosp } \\
\text { ate } \\
\text { rock }\end{array}$ & 36,340 & $57,033.5$ & 77,727 & 49,060 \\
\hline $\begin{array}{c}\text { Anti } \\
\text { foam }\end{array}$ & 13,985 & 36,209 & 58,433 & 35,113 \\
\hline \multicolumn{4}{|c|}{ TOTAL } & 84,173 \\
\hline
\end{tabular}

$$
\sum_{i=1}^{n} m_{i} y_{i} \leq A
$$

\section{$84,173 \leq 80.000$}

Dikarenakan nilai $\sum_{i=1}^{n} m_{i} y_{i} \leq A$ tidak memenuhi kendala kapasitas gudang maka perhitungan tidak dilanjutkan maka perhitungan dilanjutkan dengan Multi Item $E O Q$ with storage Limitation dengan rumus:

$$
Q_{i}^{*}=\sqrt{\frac{2 D_{i} k_{i}}{h_{i}-2 \lambda * a_{i}}}
$$

Dengan demand bersifat fuzzy sehingga rumus dapat berubah menjadi :

$$
Q_{i}^{*}=\sqrt{\frac{2 D_{i} k_{i}}{h_{i}-2 \lambda * a_{i}}}
$$

Nilai $\lambda^{*}$ sendiri diperoleh dengan cara trial dan eror dengan memasukkan nilai $\lambda^{*}$ sehingga menghasilkan ukuran pemesanan ekonomis yang sesuai dengan kapasitas yang ada. Kita coba $\lambda^{*}=-100$
Sehingga memunculkan fungsi keanggotaan untuk pemesanan yang ekonomis dalam bentuk fuzzy $\left(\tilde{y}_{i}{ }_{i}\right)$ adalah:

$$
\begin{aligned}
& \mu_{r}(r) \\
& =\left\{\begin{array}{cl}
0 & x \leq 3612.69 ; x \geq 5283.53 \\
\left(12302 \times 10^{-7}\right) y^{2}-17561 & 3612.69 \leq x \leq 4525.86 \\
37562-\left(12302 \times 10^{-7}\right) y^{2} & 4525.86 \leq x \leq 5283.53
\end{array}\right.
\end{aligned}
$$

Selanjutnya dilakukan penegasan (defuzzyfikasi) dengan metode centeroid sehingga didapatkan ukuran pemesanan ekonomis bahan baku phosphate rock sebesar 26,311 MT.

Tabel 4.3 Hasil perhitungan dengan pendekatan trial dan eror nilai lamda

\begin{tabular}{|c|c|c|c|c|}
\hline \multirow{2}{*}{$\begin{array}{c}\text { Lamda } \\
\left(\lambda^{*}\right)\end{array}$} & $\begin{array}{c}\text { Phospate } \\
\text { rock }\end{array}$ & $\begin{array}{c}\text { Anti } \\
\text { foam }\end{array}$ & \multirow{2}{*}{ Total } & $\sum_{i=1}^{n} m_{i} y_{i} \leq A$ \\
\hline 0 & 49,060 & 35,113 & 84,173 & $+4,173$ \\
\hline-100 & 26,311 & 32,054 & 78,985 & $-20,808$ \\
\hline
\end{tabular}

Sehingga didaptkan perhitungan pemesanan optimal (EOQ) bahan baku asam fosfat

Tabel 4.4 Pemesanan optimal (EOQ) bahan baku asam fosfat dengan kendala kapasitas

\begin{tabular}{|c|c|c|}
\hline No. & Bahan Baku & EOQ \\
\hline 1 & Asam sulfat & 3,808 \\
\hline 2 & Phospate Rock & 26,311 \\
\hline 3 & Anti foam & 32,054 \\
\hline
\end{tabular}

Penentuan Frekuensi Pemesanan Bahan

Baku 
Frekuensi pemesanan bahan baku dengan

metode EOQ dapat dicari dengan persamaan:

$$
F=\frac{D}{E O Q}
$$

Dan perhitungan waktu siklus dengan rumus :

$$
t_{0}=\frac{E O Q}{D} \times 360
$$

Tabel 4.5 Frekuensi pemesanan bahan baku asam fosfat dengan kendala kapasitas

\begin{tabular}{|c|c|c|c|c|c|}
\hline $\begin{array}{c}\text { Bahan } \\
\text { Baku }\end{array}$ & $\begin{array}{c}\text { Demand } \\
\text { per } \\
\text { tahun }\end{array}$ & EOQ & $\begin{array}{c}\text { Waktu } \\
\text { Siklus }\end{array}$ & $\begin{array}{c}\text { Frekuensi } \\
\text { Pemesanan }\end{array}$ & $\begin{array}{c}\text { Lead } \\
\text { Time }\end{array}$ \\
\hline $\begin{array}{c}\text { Asam } \\
\text { Sulfat }\end{array}$ & 427,318 & 3,808 & 3 hari & 112 kali & $\begin{array}{c}7 \\
\text { hari }\end{array}$ \\
\hline $\begin{array}{c}\text { Phospate } \\
\text { Rock }\end{array}$ & 690,804 & 46,931 & 24 hari & 15 kali & $\begin{array}{c}14 \\
\text { hari }\end{array}$ \\
\hline $\begin{array}{c}\text { Anti } \\
\text { foam }\end{array}$ & 294,237 & 32,054 & 39 hari & 9 kali & $\begin{array}{c}30 \\
\text { hari }\end{array}$ \\
\hline
\end{tabular}

\section{Biaya Persediaan}

Biaya persediaan diperoleh dengan menggunakan rumus:

$$
\begin{gathered}
\widetilde{T I C}=\sqrt{2 \cdot k_{I} \cdot h_{i} \cdot \widetilde{D}} \\
T I C^{2}=2 \cdot k_{I} \cdot h_{i} \cdot(a+a(b-a))
\end{gathered}
$$

Dan,

$$
T I C^{2}=2 \cdot k_{I} \cdot h_{i} \cdot(c+a(c-b))
$$

Dan selanjutnya menentukan biaya persediaan dengan rumus :

$$
\widetilde{T I C}=\frac{K_{i} \widetilde{D}}{\tilde{y} 1}+\frac{h_{i} \widetilde{y 1}}{2}
$$

Sehingga memunculkan fungsi keanggotaan untuk biaya persediaan dalam bentuk fuzzy $\left.\overline{(\text { TIC }} i^{*}\right)$ adalah:
Selanjutnya dilakukan penegasan (defuzzyfikasi) dengan metode centeroid sebagai berikut :

$$
r=\text { Defuzzikasi, } \tilde{r}=\frac{\int_{R} r \cdot \mu_{r}(r) d r}{\int_{R} \mu_{\tilde{r}}(r) d r}
$$

\begin{tabular}{|c|c|c|c|c|}
\hline \multirow{2}{*}{ 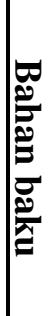 } & \multicolumn{3}{|c|}{ Nilai Fuzzy Biaya Persediaan } & \multirow{2}{*}{$\begin{array}{c}\text { Biaya } \\
\text { Perse } \\
\text { diaan } \\
\text { (Hasil } \\
\text { Defuz } \\
\text { zifika } \\
\text { i) }\end{array}$} \\
\hline & $\underset{\mathbf{m}}{\operatorname{Minimu}}$ & Tengah & $\begin{array}{l}\text { Maksim } \\
\text { um }\end{array}$ & \\
\hline 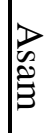 & $\begin{array}{c}\text { Rp.35,69 } \\
6,679\end{array}$ & $\begin{array}{c}\mathrm{Rp} .44,579 \\
, 465\end{array}$ & $\begin{array}{c}\text { Rp. } 53,4 \\
62,251\end{array}$ & $\begin{array}{c}\text { Rp. } 43 \text {, } \\
740,87 \\
6\end{array}$ \\
\hline 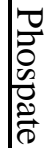 & $\begin{array}{c}\text { Rp. } 48,33 \\
1,564\end{array}$ & $\begin{array}{c}\text { Rp. } 58,768 \\
, 913\end{array}$ & $\begin{array}{c}\text { Rp.63,5 } \\
67,432\end{array}$ & $\begin{array}{c}\text { Rp.57, } \\
876,55 \\
6\end{array}$ \\
\hline 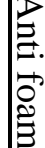 & $\begin{array}{c}\text { Rp. } 95,67 \\
5,245\end{array}$ & $\begin{array}{c}\text { Rp. } 122,87 \\
1,432\end{array}$ & $\begin{array}{l}\text { Rp.127, } \\
659,118\end{array}$ & $\begin{array}{c}\text { Rp. } 12 \\
4,562 \\
119\end{array}$ \\
\hline 夏 & $\begin{array}{c}\text { Rp. } 179,7 \\
03,488\end{array}$ & $\begin{array}{c}\text { Rp. } 226,21 \\
9,810\end{array}$ & $\begin{array}{l}\text { Rp.244, } \\
688,801\end{array}$ & $\begin{array}{c}\text { Rp.22 } \\
6,179, \\
551\end{array}$ \\
\hline
\end{tabular}

Selanjutnya dilakukan penegasan (defuzzyfikasi) dengan metode centeroid sehingga didapatkan biaya persediaan sebesar 43,740,876.11.

Tabel 4.6 Biaya persediaan bahan baku asam fosfat dengan kendala kapasitas 


\section{ANALISIS DAN INTEPRETASI} DATA

Analisis dan intepretasi hasil perhitungan Fuzzy Economic Order Quantity untuk menentukan ROP

Tabel 5.1 Kebutuhan bahan baku asam fosfat

\begin{tabular}{|c|c|c|c|}
\hline $\begin{array}{c}\text { Bahan } \\
\text { Baku }\end{array}$ & $\begin{array}{c}\text { Demand } \\
\text { per } \\
\text { tahun }\end{array}$ & $\begin{array}{c}\text { Rata-rata } \\
\text { demand } \\
\text { per bulan }\end{array}$ & $\begin{array}{c}\text { Rata- } \\
\text { rata } \\
\text { demand } \\
\text { per hari }\end{array}$ \\
\hline $\begin{array}{c}\text { Asam } \\
\text { sulfat }\end{array}$ & 427,318 & 35,609 & 1,187 \\
\hline $\begin{array}{c}\text { Phospate } \\
\text { rock }\end{array}$ & 690,804 & 57,567 & 1,919 \\
\hline Anti foam & 294,237 & 24,519 & 817 \\
\hline
\end{tabular}

Jadi titik pemesanan kembali (ROP) untuk bahan baku asam sulfat pada posisi persediaan berada pada titik di mana persediaan tersebut dapat digunakan untuk memenuhi kebutuhan 7 hari yakni pada saat persediaan di gudang sebesar 1,187 x $7=8,309$ ton. Untuk lebih jelasnya dapat dilihat pada tabel 5.2

Tabel 5.2 Titik pemesanan kembali (Reorder point)

\begin{tabular}{|c|c|c|c|}
\hline $\begin{array}{c}\text { Bahan } \\
\text { Baku }\end{array}$ & $\begin{array}{c}\text { Rata-rata } \\
\text { demand } \\
\text { per hari }\end{array}$ & $\begin{array}{c}\text { Lead time } \\
\text { pemesanan }\end{array}$ & ROP \\
\hline $\begin{array}{c}\text { Asam } \\
\text { sulfat }\end{array}$ & 1,187 & 7 hari & 8,309 \\
\hline $\begin{array}{c}\text { Phospate } \\
\text { rock }\end{array}$ & 1,919 & 14 hari & 26,865 \\
\hline Anti foam & 817 & 30 hari & 24,519 \\
\hline
\end{tabular}

Analisis total biaya persediaan bila perusahaan menggunakan Fuzzy EOQ with Limitation Storage

Dengan ditentukannya besarnya pemesanan yang ekonomis dengan menggunakan Fuzzy EOQ with Limitation Storage maka besarnya biaya persediaan yang harus ditanggung oleh perusahaan sebesar Rp.230,417,862 per bulan. Biaya total persediaan tersebut adalah hasil yang paling kecil jika dibandingkan dengan perhitungan menggunakan Fuzzy EOQ tanpa kendala kapasitas, nilai tengah fuzzy permintaan dan kondisi yang saat ini terjadi, untuk lebih jelasnya perbandingan tersebut dapat dilihat pada (Tabel 5.3).

Tabel 5.3 Perbandingan Biaya Persediaan

\begin{tabular}{|c|c|}
\hline & TIC \\
\hline January & Rp. 401,056,945 \\
\hline February & Rp. 425,898,907 \\
\hline March & Rp. $264,587,643$ \\
\hline April & Rp. 424,536,924 \\
\hline May & Rp. 290,628,902 \\
\hline June & Rp. 450,219,391 \\
\hline July & Rp. 413,287,608 \\
\hline August & Rp. 334,813,841 \\
\hline September & Rp. 437,863,967 \\
\hline October & Rp. 483,701,933 \\
\hline November & Rp. 501,420,289 \\
\hline December & Rp. 354,246,761 \\
\hline Rata-rata per bulan & Rp. 398,521,926 \\
\hline Fuzzy EOQ & Rp. 234,630,036 \\
\hline $\begin{array}{c}\text { Fuzzy EOQ } \text { with } \\
\text { storage limitation }\end{array}$ & Rp. 226,179,551 \\
\hline $\begin{array}{c}\text { EOQ with storage } \\
\text { limitation(Nilai } \\
\text { tengah permintaan) }\end{array}$ & Rp. 226,219,810 \\
\hline
\end{tabular}

Dengan hasil perhitungan tersebut jika metode Fuzzy EOQ with Limitation Storage digunakan untuk melakukan pemesanan pada tahun 2019 maka akan menghasilkan penghematan biaya persediaan yang dapat dilihat pada tabel 5.4. 
Tabel 5.4 Penghematan Biaya kondisi saat ini dengan metode Fuzzy EOQ with storage

Elimination

\begin{tabular}{|c|c|c|c|}
\hline Bula & $\begin{array}{c}\text { Sistem } \\
\text { Persediaa } \\
\text { n } \\
\text { Perusahaa } \\
\text { n (min- } \\
\text { max) }\end{array}$ & $\begin{array}{c}\text { Fuzzy } \\
\text { EOQ with } \\
\text { storage } \\
\text { limitation }\end{array}$ & $\begin{array}{l}\text { Pengl } \\
\tan B\end{array}$ \\
\hline January & $\begin{array}{r}\text { Rp.40 } \\
1,1\end{array}$ & 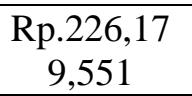 & 1, \\
\hline $\begin{array}{c}\text { Febru } \\
y \\
\end{array}$ & $\begin{array}{r}\text { Rp. } 4 \\
4,3 \\
\end{array}$ & $\begin{array}{r}\text { Rp.2 } \\
9,\end{array}$ & $\begin{array}{c}\text { Rp. } 199,36 \\
4,832 \\
\end{array}$ \\
\hline Marc & $\begin{array}{r}\mathrm{Rp} .2 \\
0,5 \\
\end{array}$ & 17 & $\begin{array}{c}\text { Rp.38,230, } \\
998\end{array}$ \\
\hline April & $\begin{array}{r}\text { Rp. } 4 \\
2,4 \\
\end{array}$ & $\begin{array}{r}\mathrm{Rp} .2 \\
9,\end{array}$ & $\begin{array}{c}\text { Rp.198,00 } \\
2,849 \\
\end{array}$ \\
\hline May & $\begin{array}{r}\text { Rp. } 2 \\
1,4\end{array}$ & 17 & $\begin{array}{c}\text { Rp.64,271, } \\
921\end{array}$ \\
\hline June & $\begin{array}{r}\text { Rp.4 } \\
3,4\end{array}$ & 17 & $\begin{array}{c}\text { Rp. } 223,77 \\
3,926\end{array}$ \\
\hline July & 2 , & 17 & $\begin{array}{l}84 \\
9\end{array}$ \\
\hline A & $\begin{array}{r}\mathrm{Rp} .3 \\
6,\end{array}$ & 17 & $\begin{array}{l}45 \\
4\end{array}$ \\
\hline $\begin{array}{c}\text { Septem } \\
\text { ber }\end{array}$ & $\begin{array}{r}\text { Rp.43 } \\
2,0 \\
\end{array}$ & $\begin{array}{r}\mathrm{Rp} .2 \\
9,\end{array}$ & $\begin{array}{r}\mathrm{Rp} .2 \\
2,\end{array}$ \\
\hline Octol & $\begin{array}{r}\mathrm{Rp} .48 \\
6,1\end{array}$ & $\begin{array}{r}\mathrm{Rp} .2 \\
9,5\end{array}$ & $\begin{array}{c}\text { Rp. } 257,25 \\
6,636\end{array}$ \\
\hline $\begin{array}{l}\text { Novem } \\
\text { ber }\end{array}$ & $\begin{array}{c}\text { Rp.501,24 } \\
3,111\end{array}$ & $\begin{array}{c}\text { Rp.226,17 } \\
9,551\end{array}$ & $\begin{array}{c}\text { Rp. } 275,06 \\
3,560\end{array}$ \\
\hline $\begin{array}{c}\text { Decem } \\
\text { ber }\end{array}$ & $\begin{array}{c}\text { Rp.354,06 } \\
9,289\end{array}$ & $\begin{array}{c}\text { Rp. } 226,17 \\
9,551\end{array}$ & $\begin{array}{c}\text { Rp. } 127,88 \\
9,738\end{array}$ \\
\hline Rata- & $\begin{array}{c}\text { Rp. } 398,25 \\
6,068\end{array}$ & $\begin{array}{c}\text { Rp.226,17 } \\
9,551\end{array}$ & $\begin{array}{c}\text { Rp. } 172,07 \\
6,517\end{array}$ \\
\hline
\end{tabular}

\section{KESIMPULAN}

Dari hasil pengolahan data dapat ditarik kesimpulan :

1. Nilai ukuran pemesanan ekonomis untuk masing-masing bahan baku asam fosfat adalah sebagai berikut : bahan baku asam sulfat sebesar 3,808 MT, bahan baku phospate rock 26,311 MT, dan bahan baku Anti foam 32,054 MT. Sehingga dapat disimpulkan dengan menggunakan fuzzy ukuran pemesanan yang sebaiknya dipesan untuk bahan baku asam sulfat dan phospate rock lebih kecil dari ukuran pemesanan yang saat ini dilakukan oleh perusahaan dengan frekuensi pemesanan asam sulfat lebih sering dan lebih sedikit frekuensi pemesanannya pada phospate rock. Sedangkan untuk bahan baku Anti foam ukuran pemesanan yang sebaiknya dilakukan oleh perusahaan lebih besar dari yang saat ini dilakukan dengan frekuensi pemesanan meningkat.

2. Titik pemesanan kembali (ROP) pada setiap pemesanan berada pada posisi jumlah persediaan yang berbeda-beda, yaitu asam sulfat pada posisi persediaan 8,309 MT atau 7 hari sebelum bahan baku habis, phospate rock pada posisi persediaan 26,865 MT atau 14 hari sebelum bahan baku habis, dan anti foam pada posisi persediaan 24,519 MT atau 30 hari sebelum bahan baku habis.

3. Dengan ditentukannya besarnya pemesanan yang ekonomis dengan menggunakan Fuzzy EOQ with Limitation Storage yang rinciannya seperti pada kesimpulan 1, maka besarnya biaya persediaan yang harus ditanggung oleh perusahaan sebesar Rp. 226,179,551 per bulan. Biaya total persediaan tersebut adalah hasil yang paling kecil jika dibandingkan dengan perhitungan menggunakan nilai tengah fuzzy permintaan 
sebesar Rp. 226,219,810 dan kondisi yang saat ini terjadi di mana rata-rata menghasilkan Rp. 398,521,926. Sehingga rata-rata penghematan per bulan yang dapat dihasilkan jika menggunakan fuzzy EOQ adalah Rp. 172,076,517.

\section{DAFTAR PUSTAKA}

Dahdah, S. S. (2009). Aplikasi Teori Himpunan Fuzzy Dalam Penentuan Ukuran Pemesanan Yang Ekonomis. MATRIK (Jurnal Manajemen dan Teknik Industri - Produksi), 12(2), 88-99.

Dutta, P., Boruah, H., \& Ali, T. (2011). Fuzzy Arithmetic wth and without using a-cut method: A Comparitive Study. International Journal of Latest Trends in Computing, 2(1), 99-107.

Efendi, H. D. (2015). Perencaaan Persediaan Multi-Item Packaging Material Dengan Kendala Keterbatasan Kapasitas Tempat Penyimpanan Menggunakan Metode Multi Item Fuzzy Economic Order Quantity Di PT. Wilmar Nabati Indonesia Departemen Consumer Pack. Gresik: Fakultas Teknik Universitas Muhammadiyah Gresik.

Kusumadewi, S., \& Purnomo, H. (2010). Aplikasi Logika Fuzzy Untuk Pendukung Keputusan (2nd ed.). Yogyakarta: Graha Ilmu.

Liu, S.-T. (2008). Fuzzy Profit Measure For a Fuzzy Economic Order Quantity Model. Applied Mathematical Modelling, 32(10), 2076-2086.

Samal, N., \& Pratihar, D. (2014). Optimization of variable demand fuzzy economic order quantity inventory. Computers \& Industrial Engineering, 1-31.

Sulistiawan, Z., \& Pribadi, F. (2017). Studi Perancangan Model Penentuan Jumlah Pemesanan dan Reorder Point menggunakan Fuzzy Inventory Control terhadap nilai persediaan. Proceeding Health Architecture, 1(1), 235-244.

Hidayat, H., Jufriyanto, M., \& Rizqi, A. (2021). Perancangan RCM (Reliability Centered Maintenance) Untuk Mengurangi Downtime Mesin Pembuat Botol (Studi Kasus PT IGLAS (Persero), Gresik). MATRIK : Jurnal Manajemen Dan Teknik Industri Produksi, 21(2), 157 - 164. doi:10.30587/matrik.v21i2.2038

Hidayat, H. (2020). Application of the EOQ (Economic Order Quantity) Method in Determining Chemical Supplies in PT. Semen Indonesia. International Journal of Science, Engineering and Information Technology, 5(1), 226230.

Hidayat, Jufriyanto, M., Wasiur, A., \& Ningtyas, A. H. P. (2020). Analysis Of Load Variations On ST 60 Steel Using Vickers Method. International Journal of Science, Engineering and Information Technology, 05(02), 5-9. https://doi.org/10.21107/ijseit.v5i1.89 40 